\title{
DEVELOPMENT AND IMPLEMENTATION METHODS MULTICRITERIA EVALUATION OF EFFICIENCY ENERGY SAVING ACTIVITIES IN THE FIELD OF HEAT SUPPLY
}

\section{Polyvianchuk A. P., Belousov I. V., Semenenko R. A.}

\section{INTRODUCTION}

In recent years, a significant number of cities in Ukraine, in particular, Kyiv, Kharkiv, Lviv, Ternopil, Chernivtsi and others. have joined the Covenant of Mayors on Climate and Energy ${ }^{1}$, which provides for the holding municipal authorities measures to significantly reduce greenhouse gas emissions by $30 \%$ by 2030 . Achieving this result requires a new strategy for the use and development of the municipal energy system, which envisages increasing the environmental safety of boiler plants and thermal power plants through the introduction of innovative high-efficiency energy-saving, environmental and economically sound technologies ${ }^{2}$. This strategy should take into account such problems of the Ukrainian economy as: outdated technologies and equipment for thermal energy production, high energy consumption and material costs exceeding 2-3 times the corresponding indicators of developed countries; lack of modern environmental protection systems, lack of appropriate legal and economic mechanisms that would encourage the development of environmentally friendly technologies, environmental protection techniques, etc. ${ }^{3}$ At the same time, stimulating the effective consumption of thermal energy by users will allow reduce

${ }^{1}$ The Covenant of Mayors for Climate and Energy Reporting Guidelines / Covenant of Mayors \& Mayors for climate and energy. Adapt Offices and the Joint Research Centre of the European Commission, 2016. 78 p.

${ }^{2}$ Alibekova A., Shaimerdenova G., Agilbaeva M. Ecolodica problems of thermal power plants. Journal of Industrial Technology and Engineering. 2013. Вип. 4(09). Pp. 40-44.

3 Варламов Г.Б., Дідик І.С. Основні особливості реалізації принципу екологічної рівноваги на екологічному об'єкті. Молодий вчений. 2016. Вип. 1, Ч. 3. С. 104-107. 
the resource consumption of urban heating networks, which will reduce environmental pollution and reduce greenhouse gas emissions ${ }^{4}$.

Actual scientific task that confronts the communal sector of the economy today is to increase the informative methods for assessing the effectiveness of measures energy saving in the areas of heat supply and heat consumption. To solve this problem, the effectiveness of the measures under study should be considered as a complex value, which takes into account the energy, environmental and economic consequences of their implementation.

The purpose of this work was to create and practical implementation method of multicriteria assessment of the effectiveness of energy saving measures with thermal energy of buildings by indicators of energy, environmental and economic effects. To achieve this goal, the following tasks were solved:

1) the creation of a multi-criteria method for evaluating the effectiveness of energy conservation measures in the field of heat supply;

2) realization of the created method for assessing the effectiveness of energy-saving measures recommended for implementation at full-scale facilities.

\section{The method of multi-criteria evaluation of the effectiveness of energy-saving measures}

The essence of this method is that the overall effectiveness of energysaving measures is considered as a 3-component vector $\mathrm{E}$, components of which are energy $-\mathrm{E}_{\mathrm{I}}$, environmental $-\mathrm{E}_{\mathrm{II}}$ and economic $-\mathrm{E}_{\mathrm{III}}$ effects of their implementation (Fig. 1).

${ }^{4}$ Маляренко В.А., Щербак І.С. Аналіз споживання паливно-енергетичних ресурсів України та їх раціонального використання. Вісник НТУ «ХПI». Серія: Енергетичні та теплотехнічні процеси й устаткування. 2013. Вип. 14(988). C. 118-126. 


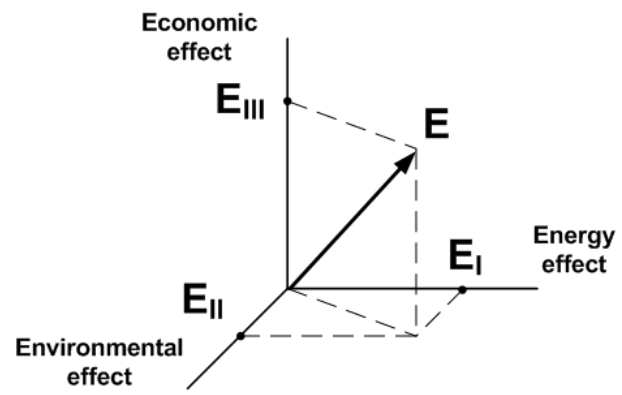

Fig. 1. Components of the overall effectiveness of energy conservation measures in the field of heat supply

At the same time, the following indicators are used to assess these components of overall efficiency:

- for energy effect $E_{l}$ : absolute $-\Delta \mathrm{Q}(\mathrm{kW} \cdot \mathrm{h})$ and relative $-\delta \mathrm{Q}(\%)$ value of the saved amount of thermal energy for the heating period, which are determined by the formulas:

$$
\Delta Q=Q_{t o t 1}-Q_{t o t 2},
$$

where $\mathrm{Q}_{\text {tot1 }}$ and $\mathrm{Q}_{\text {tot2 }}$ are the total heat losses due to the building enclosure during the heating period before and after the implementation of energy-saving measures, respectively, kWh;

$$
\delta Q=\frac{Q_{t o t 1}-Q_{t o t 2}}{Q_{t o t 1}} \cdot 100 \%
$$

- for environmental effect $E_{I I}$ : mass (volume) of fuel saved $-\Delta \mathrm{M}_{\text {fuel }}$ $(\mathrm{kg})\left(\Delta \mathrm{V}_{\text {fuel }}\left(\mathrm{m}^{3}\right)\right)$, reduction of mass of greenhouse gas emissions, in particular - of $\mathrm{CO}_{2}$ and pollutants $-\Delta \mathrm{M}_{\mathrm{p}}(\mathrm{kg})$ :

$$
\Delta M_{\text {fuel }}=3,6 \cdot \frac{\Delta \mathrm{Q}}{\mathrm{Q}_{1}},
$$

where $\mathrm{Q}_{\mathrm{l}}$ - the lower heat of combustion of the fuel, $\mathrm{MJ} / \mathrm{kg}$; 


$$
\Delta V_{\text {fuel }}=\frac{\Delta \mathrm{M}_{\text {fuel }}}{\rho_{\text {fuel }}},
$$

where $\rho_{\text {fuel }}-$ density of fuel, $\mathrm{kg} / \mathrm{m}^{3}$;

$$
\Delta M_{3 P}=3,6 \cdot 10^{-3} \cdot K_{P} \cdot \Delta \mathrm{Q},
$$

where $\mathrm{K}_{\mathrm{P}}-$ coefficient pollutant emissions $^{5}$, g/GJ;

- for economic effect $E_{I I I}$ : reduction of payment for the amount of heat consumed during the heating period $-\Delta \mathrm{C}_{\mathrm{hc}}(\mathrm{UAH})$ and for fuel $\Delta \mathrm{C}_{\text {fuel }}(\mathrm{UAH})$ :

$$
\Delta C_{h c}=9,6 \cdot 10^{-4} \cdot c_{h c} \cdot \Delta \mathrm{Q},
$$

where $c_{\mathrm{hc}}$ - the cost of a unit of thermal energy according to the set tariffs ${ }^{6}$, UAH/Gcal;

$$
\Delta C_{\text {fuel }}=10^{-3} \cdot c_{\text {fuel }} \cdot \Delta \mathrm{V}_{\text {fuel }},
$$

where $c_{\text {fuel }}$ - the cost of fuel according to the set tariffs, UAH/ton or $\mathrm{UAH} /$ ths. $\mathrm{m}^{3}$.

At assessment energy effect criteria EI total heat loss fluxes across enclosing building structure $-\mathrm{Q}_{\text {tot1 }} \mathrm{i} \mathrm{Q}_{\text {tot2 }}$ are determined using the formula $^{7}$ (Fig. 2):

$$
Q_{\text {tot }}=\left(\sum_{i=1}^{4} \mathrm{k}_{\mathrm{i}} \cdot F_{i}+c \cdot M_{\mathrm{inf}}\right) \cdot\left(\mathrm{t}_{\mathrm{in}}-\mathrm{t}_{\mathrm{out}}\right)=\mathrm{k}_{\mathrm{hl}} \cdot\left(\mathrm{t}_{\mathrm{in}}-\mathrm{t}_{\mathrm{out}}\right),
$$

where $\mathrm{k}_{\mathrm{i}}$ - the heat transfer coefficient through the ith fencing structure, $\left.\mathrm{W} /\left(\mathrm{m}^{2} \cdot \mathrm{K}\right)\right) ; \mathrm{F}_{\mathrm{i}}$ - the surface area of the $\mathrm{i}$-th fencing structure,

${ }^{5}$ Купалова І. Визначення обсягів викидів стаціонарними джерелами. Вісник. Офіційно про податки. 2016. Вип. 32(889). С. 32-37.

${ }_{6}$ Тарифи на теплову енергію для бюджетних установ. КП «Харківські теплові мережі». URL : http://www.hts.kharkov.ua/KPHTS_v2_public_ info ${ }_{\overline{7}}$ tarify.php.

${ }^{\overline{7}}$ Исаченко В.П., Осипова В.А., Сукомел А.С. Теплопередача : учебник для вузов. Энергия, 1975. 488 с. 
$\mathrm{m}^{2} ; \mathrm{c}$ - specific heat of air, $\mathrm{J} /(\mathrm{kg} \cdot \mathrm{K}) ; \mathrm{M}_{\text {inf }}{ }^{-}$mass air flow rate at infiltration, $\mathrm{kg} / \mathrm{s} ; \mathrm{t}_{\text {in }}$ - indoor air temperature, ${ }^{\circ} \mathrm{C} ; \mathrm{t}_{\text {out }}-$ outside air temperature, ${ }^{\circ} \mathrm{C}$.

$\mathrm{k}_{\mathrm{hl}}$ - heat loss coefficient, that is determined by the formula

$$
\mathrm{k}_{\mathrm{hl}}=\sum_{i=1}^{4} \mathrm{k}_{\mathrm{i}} \cdot F_{i}+c \cdot M_{\mathrm{inf}}
$$

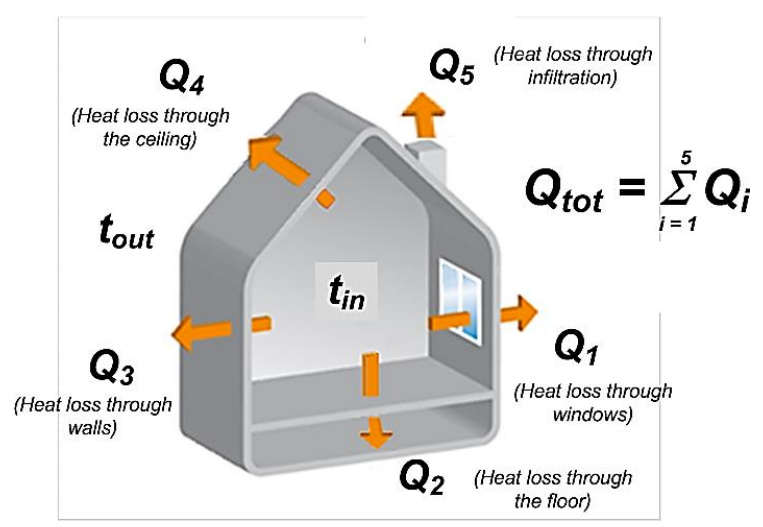

Fig. 2. Ingredients total heat losses through enclosure structures building

The presented method provides for the possibility of increasing performance indicators by adding new indicators in the components of overall efficiency. In particular, to the metric group, characterizing the economic effect of an energy-saving measure can be added to the payback period of capital investments.

\section{Evaluation of the effectiveness of energy-saving measures recommended for full-scale object № 1}

Description of the object of research. As full-scale object № 1 a fragment of the administrative building was chosen for research O.M. Beketov National University of Urban Economy in Kharkiv (O.M. Beketov NUUE), in which are located: a lecture hall, a laboratory, a conference hall and offices of the university administration. This is a three-story building with two external walls and two internal walls adjacent to heated rooms with a total heated area of $225.3 \mathrm{~m}^{2}$ (Fig. 3). 

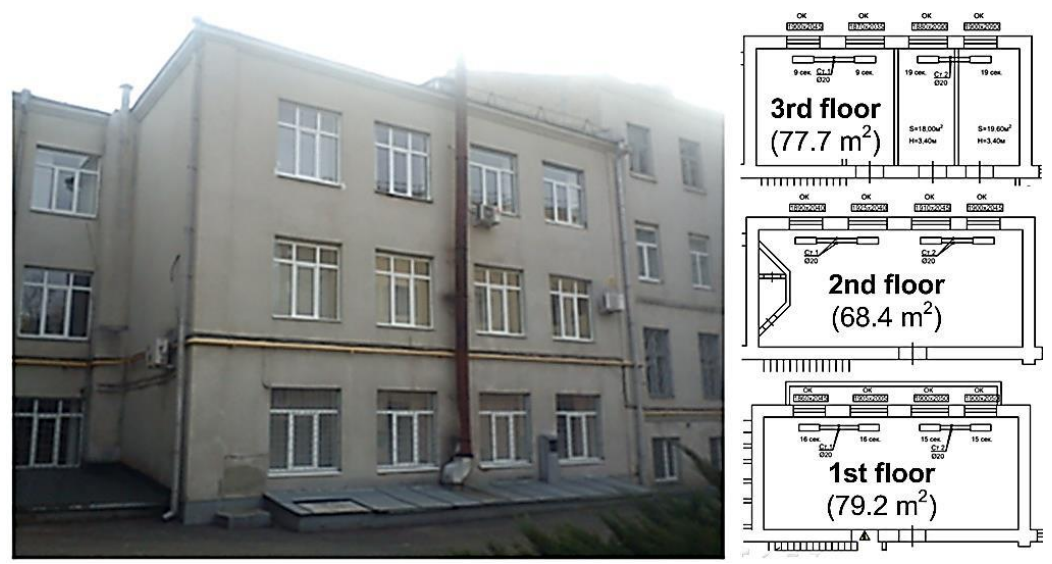

\section{Fig. 3. Full-scale object № 1 for studying the efficiency of heat consumption}

As a result of a full-scale survey of buildings, the structural parameters of the building envelope necessary for thermal calculations were obtained. According to witnesses, the average actual cost of the specific heat consumption for the entire administrative building in the heating season of 2019 was $q_{\text {averag }}=97.5 \mathrm{kWh} / \mathrm{m}^{2}$. The selected part of the building has two external walls and window openings facing north. The ratio of the total area of window openings to the area of external walls significantly exceeds the average for the entire building. Based on this, it can be assumed that the value of the specific heat consumption in the selected section of the building will exceed the average value of the specific heat consumption for the entire building in accordance with the readings of the counters. The average temperature inside the building during the heating season of 2019 was $\mathrm{t}_{\mathrm{in}}=18^{\circ} \mathrm{C}$.

Investigated energy conservation event. For full-scale object № 1 recommended use smart home technology for control thermal modes building premises using the HERZ Smart Comfort automated system ${ }^{8}$. This system is a kit of components for controling the thermal mode of premises using a smartphone. The kit includes (Fig. 4):

${ }^{8}$ HERZ Smart Comfort: дистанционное управление комфортом дома. URL : https://voltar.com.ua/news/herz-smart-comfort-distantsionnoe-upravleniekomfortom-doma.html. 
- electronic heat regulators ETKF +;

- window opening sensor;

- room thermostat;

- switching module Cube +;

- thermal switch Eco SWITCH +.

Using the HERZ Smart Comfort system is as follows. All radiators in the building are equipped with electronic heat control ETKF +. A programmable room thermostat is installed in each room, which measures the temperature in the room and gives commands to the heat regulators to open or close them. You can directly control the electronic thermal regulator in accordance with the temperature of the air in the room, however, its efficiency decreases at the same time, since the regulator is installed directly on the radiator and curtains, direct sunlight, and other factors can affect its operation. The room thermostat can be installed at the optimum height, where external factors will not affect it. Each window must have a window open sensor installed. To control thermostats using a smartphone, the system must be equipped with a Cube + module, which is located next to the router and provides an Internet connection. The Eco SWITCH + thermal mode switch is used alone for a full-scale object, it is installed in the corridor and turns on when the last employee leaves the building.

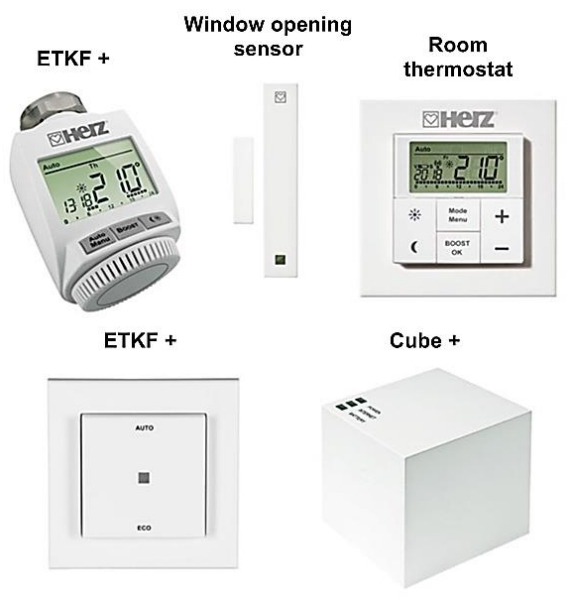

Fig. 4. Key elements of the HERZ Smart Comfort automated system 
Automated control for thermal modes building premises is as follows. A room thermostat measures the temperature in the room and through the heat controllers changes the amount of coolant passing through the radiator. When a window opens in a room, the window open sensor is activated and the room temperature is automatically maintained at $17^{\circ} \mathrm{C}$ (factory setting) or at another level set by the user. Using a wall thermostat, the hourly temperature change is set depending on the heat generation mode. For example, during the day from 8-00 to 17-00 in the event that no one is in the room, a temperature of $16^{\circ} \mathrm{C}$ can be set, which returns to $22^{\circ} \mathrm{C}$ after 17-00. In general, during the day you can set 6 tuned thermal conditions in the rooms. At the same time, these modes can be controlled using a smartphone on which special software is installed.

\section{Justification of the expediency of using an energy-saving measure.}

Advantages of HERZ Smart Comfort. The main factor ensuring the effectiveness of this heating system in the rational use of thermal energy is the dynamism of control. The temperature in each room is maintained exactly as needed at the moment, which provides HERZ Smart Comfort.

Features of HERZ Smart Comfort:

- the temperature is controlled and controlled in each room;

- it is possible to control the heating using a smartphone or laptop via the Internet;

- automatic temperature change in the room is provided at certain intervals (up to 6 periods per day);

- it is possible to remotely control the temperature in the premises when changing preset settings;

- minimized heat loss during ventilation.

According to the manufacturer of building heating control using the HERZ, Smart Comfort system saves up to $60 \%$ of thermal energy.

Evaluation of the effectiveness of the implementation of energysaving measures. As a result of the analysis of the actual need of the building's premises for comfortable heat baking, at which the indoor air temperature $-\mathrm{t}_{\mathrm{in}}{ }^{\text {comf }}$ is maintained at $20^{\circ} \mathrm{C}$, the indicator of the building's relative need for comfortable heat supply $-\gamma_{\text {comf }}$ was determined (Fig. 5):

$$
\gamma_{\text {comf }}=\sum_{i=1}^{3} \frac{S_{h a i}}{S_{h a}} \cdot \gamma_{\text {comfi }}=\frac{79,2}{225,3} \cdot 0,18+\frac{68,4}{225,3} \cdot 0,02+\frac{77,7}{225,3} \cdot 0,27=0,16,
$$


where $S_{\text {hai }}$ - the heating area of the i-th floor of the building, $\mathrm{m}^{2}$; $\gamma_{\text {comfi }}$ - relative need for comfortable heat supply of the i-th floor:

$$
\gamma_{\text {comfi }}=\frac{\tau_{h(w) i}}{\tau_{h(w)}},
$$

where $\tau_{\mathrm{h}(\mathrm{w}) \mathrm{i}}$ - the average weekly duration of the period of comfortable heat supply during the heating season for the i-th floor, h; $\tau_{\mathrm{h}(\mathrm{w})}-$ duration of one week period -168 hours.
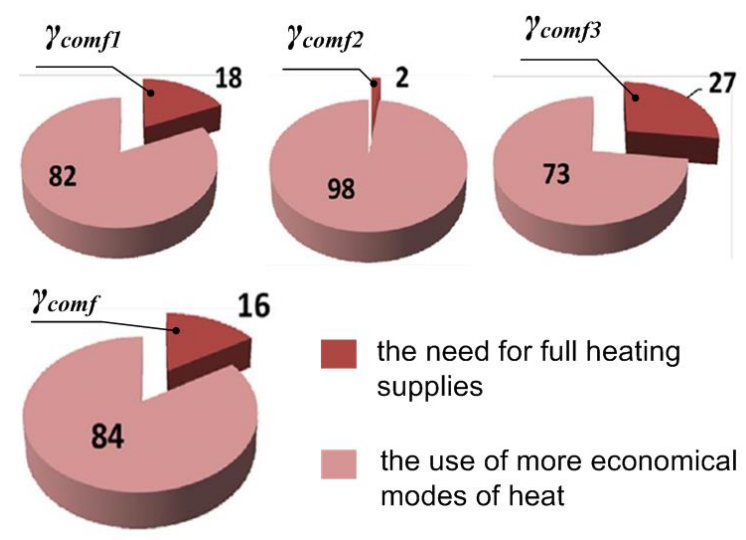
the need for full heating supplies

the use of more economical modes of heat

Fig. 5. The results of the analysis of the needs of the premises of the facility № 1 in a comfortable heat supply

In further calculations, it was assumed that in rooms requiring a comfortable warmth, the HERZ Smart Comfort system supports a comfortable thermal mode with a temperature of $\mathrm{t}_{\mathrm{in}}{ }^{\mathrm{comf}}$, and in other rooms - an economical mode with a temperature of $\mathrm{t}_{\mathrm{in}}{ }^{\text {econ }}$, which is $4^{\circ} \mathrm{C}$ lower than $\mathrm{t}_{\mathrm{in}}{ }^{\text {comf }}$ and equal to $16^{\circ} \mathrm{C}^{9}$.

Indicators of energy efficiency from the use of the system of regulation of thermal modes of premises of a full-scale object № 1 were determined by the formulas (without taking into account the thermal inertia of the building):

${ }^{9}$ Polivyanchuk A., Kovalenko Y. Improving the efficiency of thermal energy use when heating buildings through the introduction of technologies «smart home». Вісник Харківського національного університету ім. В.Н. Каразіна. Серія «Екологія», 2018. Вип. 19. С. 119-126. DOI: 10.26565/1992-4259-2018-19-12. 


$$
\begin{aligned}
& \delta Q=\left(1-\gamma_{\text {comf }}\right) \cdot \frac{t_{\text {in }}^{\text {comf }}-t_{\text {in }}^{\text {econ }}}{t_{\text {in }}^{\text {comf }}-t_{\text {out }(a)}} \cdot 100 \%= \\
& =(1-0.16) \cdot \frac{20-16}{20-(-0.8)} \cdot 100 \%=17 \%
\end{aligned}
$$

where $\mathrm{t}_{\text {out }(\mathrm{a})}=-0.8{ }^{\circ} \mathrm{C}$ - average air temperature in Kharkiv for the heating period 2019;

$$
\Delta Q=\left(q \cdot S_{h a}\right) \cdot \frac{\delta Q}{100} \cdot 10^{3}=(97,5 \cdot 225,3) \cdot \frac{17}{100}=3734 k W \cdot h,
$$

where $\mathrm{q}=97.5(\mathrm{~kW} \cdot \mathrm{h}) / \mathrm{m}^{2}$ is the actual specific heat consumption of the administrative building of O.M. Beketov NUUE in 2019 year.

According to formulas (4) - (7), the indicators of environmental and economic effects from the implementation of the energy saving measure for the heating period were determined, which were:

- reduction of natural gas consumption for heating $-\Delta \mathrm{V}_{\text {fuel }}=406.4 \mathrm{~m}^{3}$;

- reduction of $\mathrm{CO}_{2}$ and $\mathrm{NO}_{\mathrm{x}}$ emissions into the atmosphere $\Delta \mathrm{M}_{\mathrm{CO} 2}=789.1 \mathrm{~kg} ; \Delta \mathrm{M}_{\mathrm{NOx}}=0.86 \mathrm{~kg}$;

- reduction of the payment for the use of thermal energy and fuel $\Delta \mathrm{C}_{\mathrm{hc}}=4441 \mathrm{UAH}$ and $-\Delta \mathrm{C}_{\text {fuel }}=4041 \mathrm{UAH}$.

On the basis of the full-scale object № 1, which was considered as a physical model larger buildings and other types of buildings, an evaluation was carried out efficiency of the HERZ Smart Comfort system in all premises of the administrative building (heating area 5821 $\mathrm{m}^{2}$ ), all buildings of the university (heating area $51186 \mathrm{~m}^{2}$ ) and fragments of hospital and apartment buildings, the heating areas of which are the same as those of the full-scale object (Figs. 6, 7).

The results of the realization of the method of multi-criteria evaluation of the effectiveness of energy-saving measures has proved its information content and the possibility of using it during in mathematical and physical modeling of the ecological and energy state of the studied objects. 


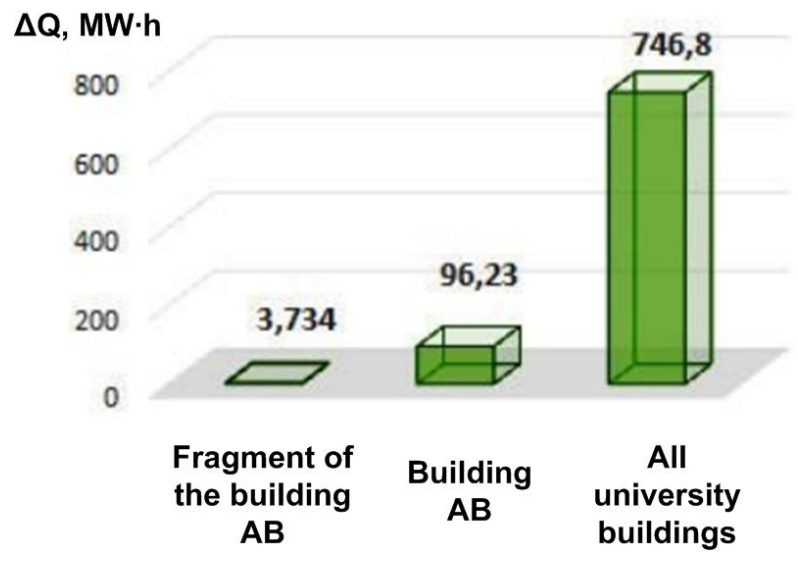

Fig. 6. Results of energy assessment effect energy saving event in O.M. Beketov NUUE

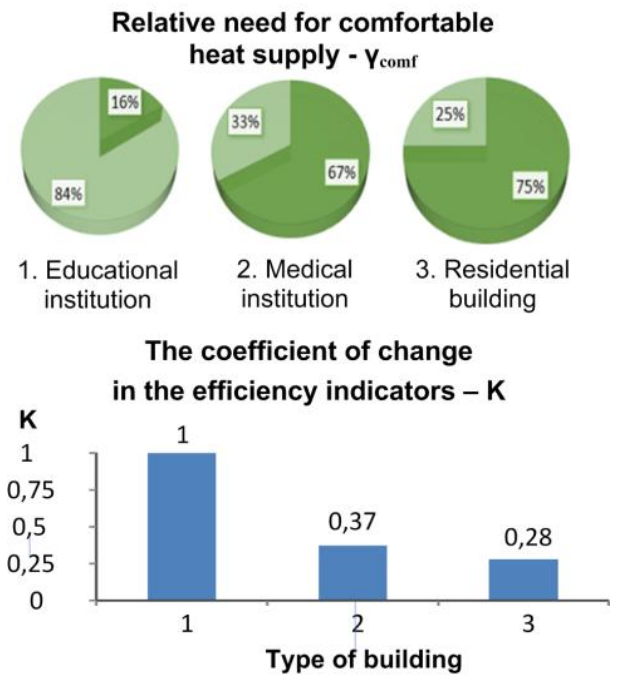

Fig. 7. Results of evaluating the effectiveness of using the HERZ Smart Comfort system in buildings of various types 


\section{Evaluation of the effectiveness of energy-saving measures recommended for full-scale object № 2}

Description of the object of research. The building of the Communal Institution "Kharkov Palace of Children and Youth Creativity" (CI KhPCYC) 1993 of the building, which consists of two buildings and has a multi-level complex T-shape (Fig. 8), was chosen as a full-scale object № 2 for research. According to the project documentation for the building: its construction volume is $80375 \mathrm{~m}^{3}$, the total area of the building is $15159 \mathrm{~m}^{2}$; usable area $13712 \mathrm{~m}^{2}$; the projected consumption of thermal energy for heating $1 \mathrm{~m}^{2}$ of the total area is $183 \mathrm{~W} / \mathrm{m}^{2}$.
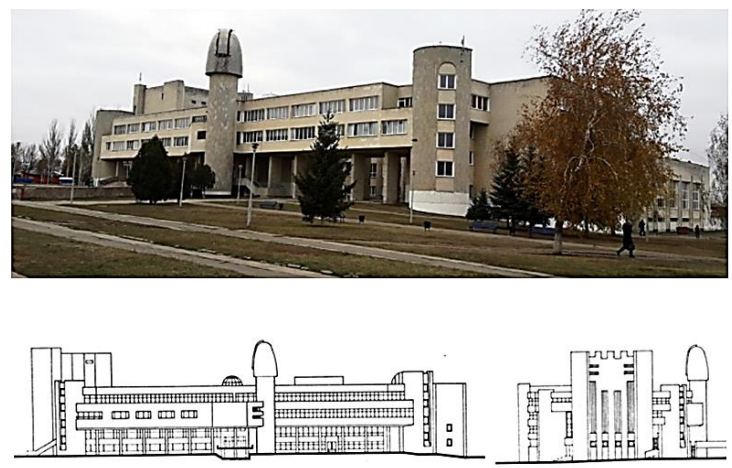

Fig. 8. General view of a full-scale object № 2

The heating of the building for the needs of heating and hot water supply is provided from the thermal networks of the enterprise of the communal enterprises "Kharkiv Thermal Networks". The actual heat consumption of a building in Gcal, averaged over 4 years, is as follows: annual - 1870.3; monthly:

$\begin{array}{lll}\text { January }-429.6 ; & \text { May }-41.8 ; & \text { September }-21.1 ; \\ \text { February }-378.6 ; & \text { June }-11.0 ; & \text { October }-128.3 ; \\ \text { March }-241.2 ; & \text { July }-0.0 ; & \text { November }-286.2 ; \\ \text { April }-104.2 ; & \text { August }-1.7 ; & \text { December }-226.7\end{array}$

Investigated energy conservation measures. For full-scale object № 2, the use of 2 energy-saving measures is recommended: controlling the thermal conditions of the building's premises with the HERZ Smart Comfort system (described above) and using an alternative source of heat supply - heliosystems. Elements of the solar system are solar collectors that convert the thermal energy of the sun into the heat energy 
of the heat carrier, which ensures the functioning of heating systems and hot water supply of the building of the CI KhPCYC building and, if necessary, other buildings. In the heliosystemy, it is recommended to use modern, energy-efficient, flat-type solar collectors, such as the Buderus (Germany) SKT $1.0^{10}$ series collectors (Fig. 9) or similar devices.

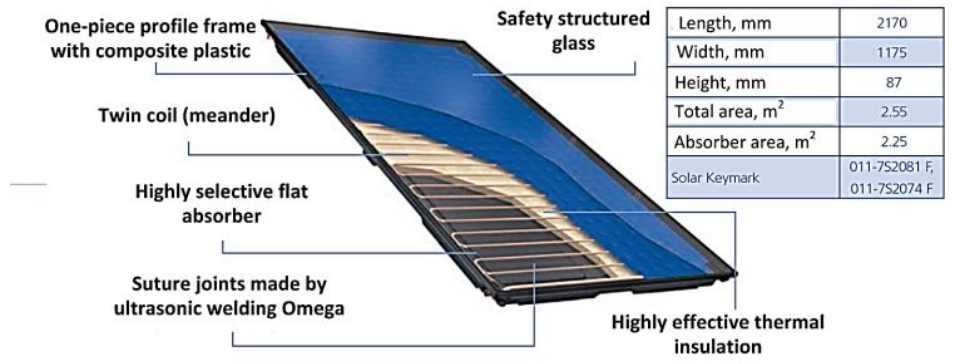

Fig. 9. Structure and technical characteristics of solar collector - SKT 1.0

The shape of the possible location of the heliosystems with a total area of $1080 \mathrm{~m}^{2}$ is located on the south side of one of the buildings of the CI KhPCYC (Fig. 10).

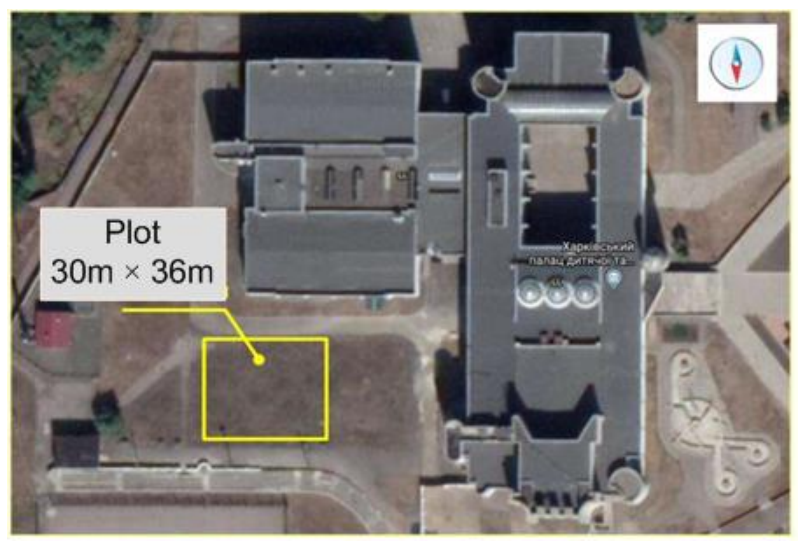

Fig. 10. The shape of the possible location of the heliosystem

10 Плоскі сонячні колектори Logasol SKT 1.0. Будерус Україна. URL : https://www.buderus.ua/products/solar/skt10.html. 
On the recommended site in accordance with established requirements ${ }^{11} 180$ collectors of the recommended type can be placed: 3 rows of 60 pieces (Fig. 11).

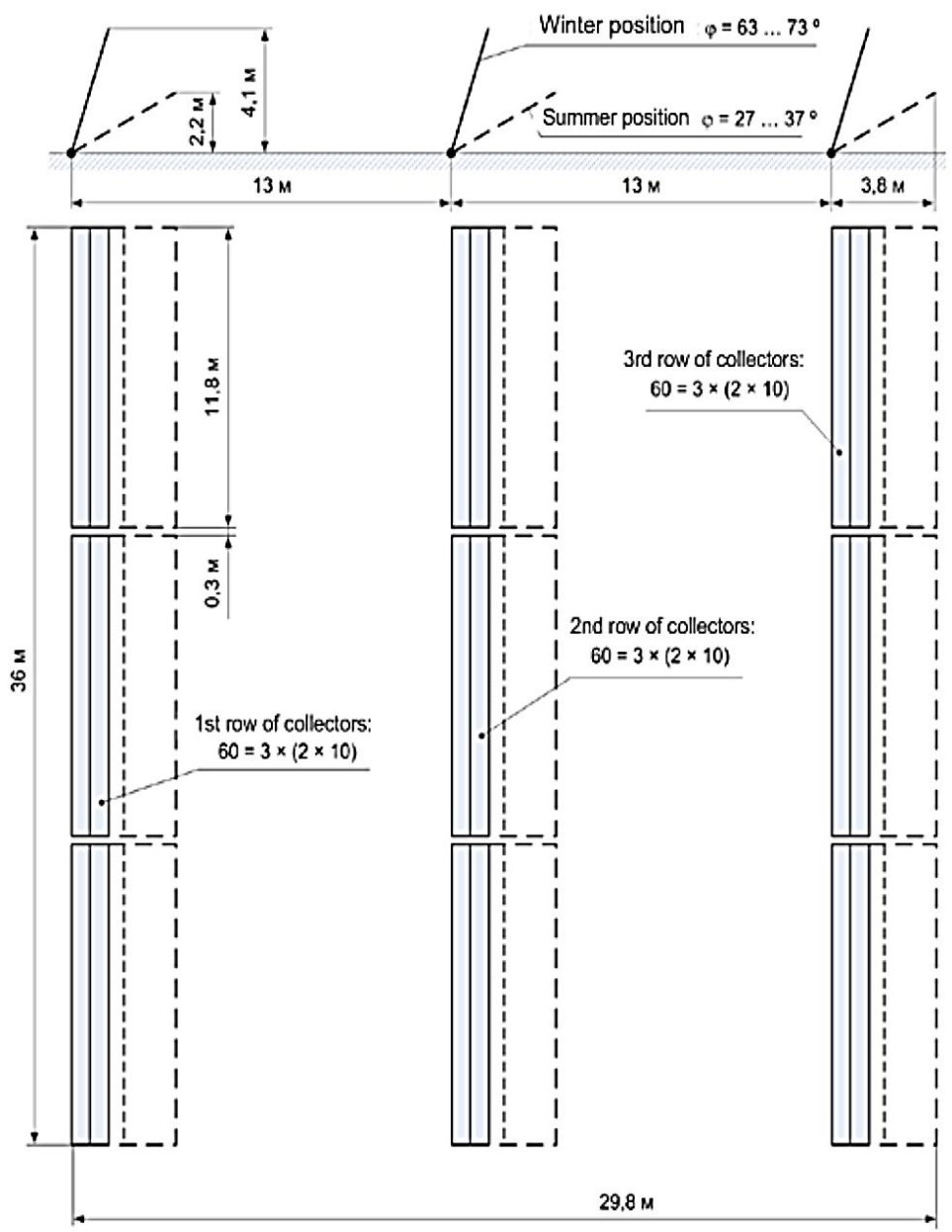

Fig. 11. Scheme arrangement of rows of solar collectors with $180=3 \times 60$ panels

11 Вовчак В., Тесленко О., Самченко О., Сушкова Д. Кращі з доступних технологій для житлово-комунального господарства України. Керівництво 3 відбору технологій / Під ред. С. Срмілова. «Поліграф плюс», 2016. 134 с. 
To ensure maximum thermal power of solar collectors (table. 1) it is recommended to adjust the angle of inclination of their panels to the earth's surface in the range of $27 \ldots 73^{\circ}$ (table. 2).

Table 1

The value of the specific average monthly thermal power of solar collectors in the Kharkiv - $E_{\mathrm{s}}$ climate zone, $\mathrm{kW} \cdot \mathrm{h} /\left(\mathrm{m}^{2} \cdot\right.$ day $)$

\begin{tabular}{|c|c|c|c|c|c|c|c|c|c|c|c|c|}
\hline \multicolumn{10}{|c|}{ Month of the year } & \multirow{2}{*}{ Year } \\
\hline $\mathbf{1}$ & $\mathbf{2}$ & $\mathbf{3}$ & $\mathbf{4}$ & $\mathbf{5}$ & $\mathbf{6}$ & $\mathbf{7}$ & $\mathbf{8}$ & $\mathbf{9}$ & $\mathbf{1 0}$ & $\mathbf{1 1}$ & $\mathbf{1 2}$ & \\
\hline 1.19 & 2.02 & 3.05 & 3.92 & 5.38 & 5.46 & 5.56 & 4.88 & 3.49 & 2.10 & 1.19 & 0.90 & 3.26 \\
\hline
\end{tabular}

Table 2

Value of optimum tilt angles of solar collectors

\begin{tabular}{|l|c|c|c|c|c|c|c|c|}
\hline \multirow{2}{*}{ Month } & \multicolumn{7}{|c|}{ Geographic latitude of the area } \\
\cline { 2 - 9 } & $\mathbf{4 5}^{\mathbf{a}}$ & $\mathbf{4 6}^{\mathbf{a}}$ & $\mathbf{4 7}^{\mathrm{a}}$ & $\mathbf{4 8}^{\mathbf{a}}$ & $\mathbf{4 9}^{\mathrm{a}}$ & $\mathbf{5 0}^{\mathrm{a}}$ & $\mathbf{5 1}^{\mathrm{a}}$ & $\mathbf{5 2}^{\mathbf{a}}$ \\
\hline 1. January & $66^{\mathrm{a}}$ & $67^{\mathrm{a}}$ & $68^{\mathrm{a}}$ & $69^{\mathrm{a}}$ & $70^{\mathrm{a}}$ & $71^{\mathrm{a}}$ & $72^{\mathrm{a}}$ & $73^{\mathrm{a}}$ \\
\hline 2. February & $58^{\mathrm{a}}$ & $59^{\mathrm{a}}$ & $60^{\mathrm{a}}$ & $61^{\mathrm{a}}$ & $62^{\mathrm{a}}$ & $63^{\mathrm{a}}$ & $64^{\mathrm{a}}$ & $65^{\mathrm{a}}$ \\
\hline 3. March & $47^{\mathrm{a}}$ & $48^{\mathrm{a}}$ & $49^{\mathrm{a}}$ & $50^{\mathrm{a}}$ & $51^{\mathrm{a}}$ & $52^{\mathrm{a}}$ & $53^{\mathrm{a}}$ & $54^{\mathrm{a}}$ \\
\hline 4. April & $36^{\mathrm{a}}$ & $37^{\mathrm{a}}$ & $38^{\mathrm{a}}$ & $39^{\mathrm{a}}$ & $40^{\mathrm{a}}$ & $41^{\mathrm{a}}$ & $42^{\mathrm{a}}$ & $43^{\mathrm{a}}$ \\
\hline 5. May & $26^{\mathrm{a}}$ & $27^{\mathrm{a}}$ & $28^{\mathrm{a}}$ & $29^{\mathrm{a}}$ & $30^{\mathrm{a}}$ & $31^{\mathrm{a}}$ & $32^{\mathrm{a}}$ & $33^{\mathrm{a}}$ \\
\hline 6. June & $22^{\mathrm{a}}$ & $23^{\mathrm{a}}$ & $24^{\mathrm{a}}$ & $25^{\mathrm{a}}$ & $26^{\mathrm{a}}$ & $27^{\mathrm{a}}$ & $28^{\mathrm{a}}$ & $29^{\mathrm{a}}$ \\
\hline 7. July & $24^{\mathrm{a}}$ & $25^{\mathrm{a}}$ & $26^{\mathrm{a}}$ & $27^{\mathrm{a}}$ & $28^{\mathrm{a}}$ & $29^{\mathrm{a}}$ & $30^{\mathrm{a}}$ & $31^{\mathrm{a}}$ \\
\hline 8. August & $32^{\mathrm{a}}$ & $33^{\mathrm{a}}$ & $34^{\mathrm{a}}$ & $35^{\mathrm{a}}$ & $36^{\mathrm{a}}$ & $37^{\mathrm{a}}$ & $38^{\mathrm{a}}$ & $39^{\mathrm{a}}$ \\
\hline 9. September & $43^{\mathrm{a}}$ & $44^{\mathrm{a}}$ & $45^{\mathrm{a}}$ & $46^{\mathrm{a}}$ & $47^{\mathrm{a}}$ & $48^{\mathrm{a}}$ & $49^{\mathrm{a}}$ & $50^{\mathrm{a}}$ \\
\hline 10. October & $55^{\mathrm{a}}$ & $56^{\mathrm{a}}$ & $57^{\mathrm{a}}$ & $58^{\mathrm{a}}$ & $59^{\mathrm{a}}$ & $60^{\mathrm{a}}$ & $61^{\mathrm{a}}$ & $62^{\mathrm{a}}$ \\
\hline 11. November & $64^{\mathrm{a}}$ & $64^{\mathrm{a}}$ & $65^{\mathrm{a}}$ & $66^{\mathrm{a}}$ & $67^{\mathrm{a}}$ & $68^{\mathrm{a}}$ & $69^{\mathrm{a}}$ & $71^{\mathrm{a}}$ \\
\hline 12. December & $68^{\mathrm{a}}$ & $69^{\mathrm{a}}$ & $70^{\mathrm{a}}$ & $71^{\mathrm{a}}$ & $72^{\mathrm{a}}$ & $73^{\mathrm{a}}$ & $74^{\mathrm{a}}$ & $75^{\mathrm{a}}$ \\
\hline
\end{tabular}

Justification of the expediency of using an energy-saving measure Recently, the interaction between energy and the environment has become dangerous character. Burning and heat energy installations carry out chemical pollution of the environment by emissions of harmful substances, first of all nitrogen and sulfur oxides, greenhouse gas emissions $-\mathrm{CO}_{2}, \mathrm{CO}$ those others, ash and soot emissions, which are steadily exacerbating environmental problems due to incareased production.

The growing technogenic burden on the environment and the exacerbation of these environmental security issues require an immediate change in environmental policy and the sustainable development of ecology in the future, energy and the economy. The solution to this problem is made possible by a clear optimization of the structure of the 
energy balance of the country, in which the largest share should be ecologically safe energy sources from renewable energy sources.

Traditional energy today accounts for at least $30 \%$ of all atmospheric emissions. Of the total emissions, about $30 \%$ are solids, more than $60 \%$ sulfuric anhydride, and about 55\% nitrogen oxides. In these conditions, the integration of energy and ecology, close interrelation of ecological aspects of energy with energy aspects of ecology is important in the region $^{12}$. The implementation of such integration is in accordance with the concept of sustainable development of society, whose main purpose is to ensure the high quality of life of present and future generations on the basis of a balanced solution to the problems of economic development, conservation of the natural environment, rational use and reproduction of the planet's natural resource potential.

An analysis of the development strategy of the EU energy sector shows that between 2020 and 2030, the relative shares in the energy balance of primary energy sources of fuels such as oil and solid fuels will decrease by $0,4 \%$ (from 35.7 to $35,3 \%$ ) ) and $0,7 \%$ (from 17,4 to 16\%), respectively, of natural gas - will not change $-25,7 \%$, and the share of renewable energy sources will increase by $3,1 \%$ (from $9,9 \%$ to $12,0 \%$ ). Thus, the contribution to the energy balance of traditional energy sources will be reduced over the years, which will lead to an increase in their cost, while, on the contrary, renewable energy sources will increase significantly ${ }^{13}$.

One of the promising areas of energy resource conservation is the utilization of solar energy due to the depletion of world oil and gas reserves, as well as the problem of environmental pollution by solid fuel combustion products. The technology of utilization of solar energy, which is most prepared for the implementation of public utilities needs, is water heating by solar energy. Ukraine's National Energy Strategy for the period up to 2030 envisages a gradual increase in the production of equipment for solar hot water supply and heating systems, and it is also planned to install about 2 million $\mathrm{m}^{2}$ of solar collectors, which will allow to obtain tangible savings. Experience in operating these systems has shown that $1 \mathrm{~m}^{2}$ of solar collector under optimal operating conditions

12 14. Дорогунцов С.І., Коценко К.Ф., М.А. Хвесик. Екологія: підручник. KHEУ, 2005. 104 c

13 Прутська О.О., Федик О.Ю. Сучасний стан та проблеми розвитку альтернативної енергетики в Україні. Збірник наукових працьь ВНАУ. 2012. Вип. 1(56). Т. 2. С. 158-164. 
saves from 0.1 to 0.15 tons of conditional fuel during the summer season. Large-scale use of solar systems in Ukraine by 2030 will save up to 200 thousand within the adopted strategy of energy industry development Tons of conditional fuel ${ }^{14}$.

Evaluation of the effectiveness of the use of the HERZ Smart Comfort system for controling the thermal modes of the premises of full-scale object № 2. An analysis of the needs of the premises of the CI KhPCYC building for comfortable heat supply showed that according to the duration of the actual use, they can be divided into 4 groups: around the clock; from 9.00 to 19.00 (except weekends) from 14.00 to 20.00; according to a special schedule (Fig. 12).

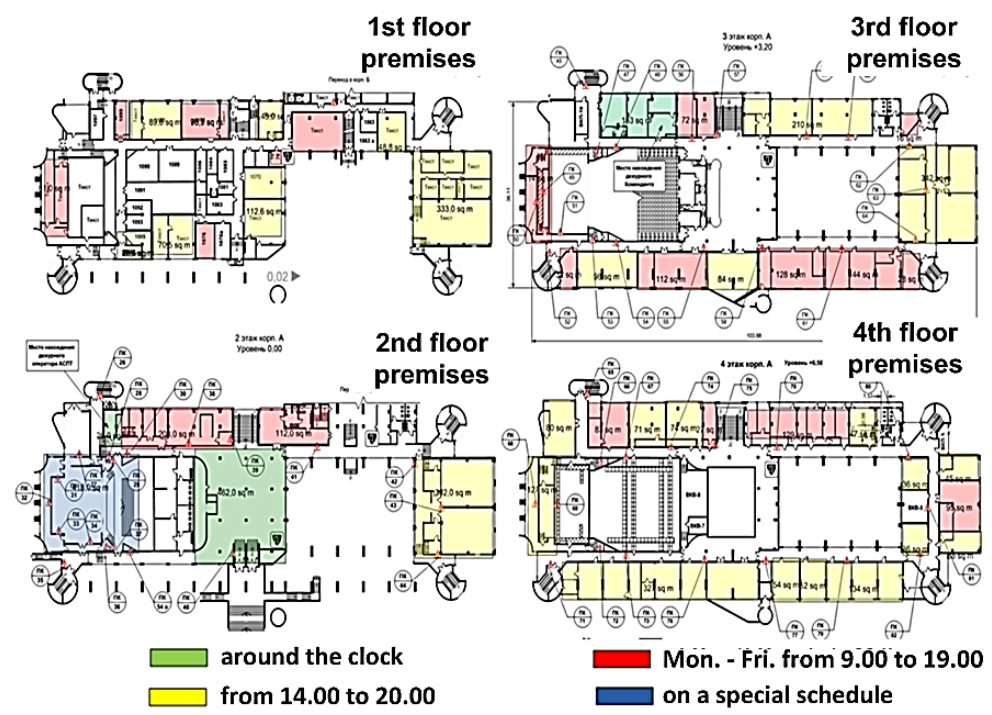

Fig. 12. The results of the analysis of the needs of the premises of the building CI KhPCYC in comfortable heat supply

In rooms that are not used around the clock, it is possible to introduce an economical mode of heat consumption by lowering the temperature during the absence of personnel and visitors. The calculation takes the

14 Штен I. Аналіз конструкцій геліосистем гарячого водопостачання, які використовуються в Україні. Збірник тез Міжнародної студентської науковотехнічної конференції Природничі та гуманітарні науки. Актуальні питання. 2018. T. 1. C. $131-132$. 
average comfortable temperature in the room equal to $20^{\circ} \mathrm{C}$. A temporary decrease in temperature is advisable if the room is not used for 10-12 hours or more, takes place in most educational and office buildings at night, on weekends and holidays. Temporary temperature reduction should not exceed $4^{\circ} \mathrm{C}$ in order to avoid violation of the humidity regime and the appearance of temperature deformations. It was assumed that the automatic control system for the thermal conditions of rooms provides a comfortable temperature only in rooms that are actually used by staff and visitors, in other rooms it maintains an economy mode temperature - less than $4^{\circ} \mathrm{C}$ from comfortable, that is $16^{\circ} \mathrm{C}$. As initial data For research, the values of the heating areas of the building's premises and the results of the analysis of their need for comfortable heat supply were used (table 3, see Fig. 12).

Table 3

Classification of the premises of the full-scale object

\begin{tabular}{|c|c|c|c|}
\hline Type of premises & Usage mode & Area, $\mathbf{~ m}^{\mathbf{2}}$ & $\begin{array}{c}\text { The fate of the } \\
\text { total area, \% }\end{array}$ \\
\hline 24-hour staff room & around the clock & 1079 & 11,9 \\
\hline Administrative premises & $\begin{array}{c}\text { Mon. - Fri. } \\
\text { from 9.00 to } 19.00\end{array}$ & 1382 & 15,3 \\
\hline $\begin{array}{c}\text { Training rooms } \\
\text { used in one shift }\end{array}$ & from 14.00 to 20.00 & 4208 & 46,6 \\
\hline $\begin{array}{c}\text { Training rooms } \\
\text { used in two shifts }\end{array}$ & from 8.00 to 18.00 & 390 & 4,3 \\
\hline $\begin{array}{c}\text { 450-seat auditorium } \\
\text { from 9.00 to } 18.00\end{array}$ & 615 & 6,8 \\
\hline Corridors & around the clock & 1365 & 15,1 \\
\hline Total area & - & 9033 & 100,0 \\
\hline
\end{tabular}

The calculations took into account the current heat tariff (excluding VAT) at the time of the research. The thermal inertia of the building was not taken into account. It was believed that heat loss, tentatively proportional to the area of the room. Optimization of heat supply over time is supposed to be carried out in the whole building, with the 
exception of rooms with round-the-clock staff stay. The following relationships were used in the calculations ${ }^{15}$.

1. Actual heat energy consumption during the heating season:

$$
Q_{a}=\mathrm{k} \cdot F \cdot \Delta \mathrm{t}_{a},
$$

where $\mathrm{k}$ - the heat transfer coefficient, $\mathrm{W} / \mathrm{m}^{2} ; \mathrm{F}$ - area of walling, $\mathrm{m}^{2}$; $\Delta \mathrm{t}_{\mathrm{a}}$ - the difference between the room temperature and the average monthly outdoor temperature in the heating season $2018-2019,{ }^{\circ} \mathrm{C}$.

From the expression (14) follows

$$
\mathrm{k} \cdot \mathrm{F}=\frac{\mathrm{Q}_{\mathrm{a}}}{\Delta \mathrm{t}_{\mathrm{a}}} .
$$

2. Estimated heat energy consumption for the average monthly outdoor temperature of the heating season for the period 1981-2019. The use of thermal control (TC) is determined by optimizing the temporary temperature of the building:

$$
Q_{e}=\mathrm{k} \cdot F \cdot \Delta \mathrm{t}_{e}=\frac{Q_{a}}{\Delta \mathrm{t}_{a}} \cdot \Delta \mathrm{t}_{e},
$$

where $\Delta \mathrm{t}_{\mathrm{e}}-$ the difference between the internal and external temperatures for the average monthly temperatures of the heating season, ${ }^{\circ} \mathrm{C}$.

3. Heat consumption after TC, Gcal:

$$
Q_{T C}=\frac{Q_{e} \cdot \tau_{16} \cdot\left(\Delta \mathrm{t}_{e}-4\right)}{\Delta \mathrm{t}_{e} \cdot \tau_{\mathrm{w}}}+\frac{Q_{e} \cdot \tau_{20}}{\tau_{\mathrm{w}}},
$$

where $\tau_{16}$ - the number of hours per week with a room temperature of $16^{\circ} \mathrm{C}, \mathrm{h} ; \tau_{20}$ - the number of hours per week with a room temperature of $20^{\circ} \mathrm{C}, \mathrm{h} ; \tau_{\mathrm{w}}-$ the number of hours in a week, $\mathrm{h}$.

The average monthly values of the actual consumption of thermal energy were adjusted taking into account the average monthly outdoor temperatures in Kharkov over a long period.

As the initial data for the calculations, we used the values of the average monthly actual consumption of thermal energy by the research object in the heating seasons of 2016-2019 (table 4).

${ }^{15}$ Исаченко В.П., Осипова В.А., Сукомел А.С. Теплопередача : учебник для вузов. Энергия, 1975. 488 с. 
Table 4

Average monthly consumption

of thermal energy by the building $-Q_{a}$, Gcal

\begin{tabular}{|c|c|c|c|c|c|c|c|}
\hline Month & January & February & March & April & October & November & December \\
\hline $\begin{array}{c}\text { Thermal } \\
\text { energy } \\
\text { consumption }\end{array}$ & 260,5 & 235,6 & 171,2 & 55,1 & 65,6 & 177,4 & 140,5 \\
\hline
\end{tabular}

Based on the above ratios estimated the level of saved heat energy in all rooms of the CI KhPCYC building, which require optimization of the temperature regime. The calculation results (Fig. 13, table 5) indicate that the use of optimizing the temperature mode of the building by lowering the temperature during the absence of staff and visitors can save 130,3 Gcal or $11,1 \%$ of heat energy during the heating season.

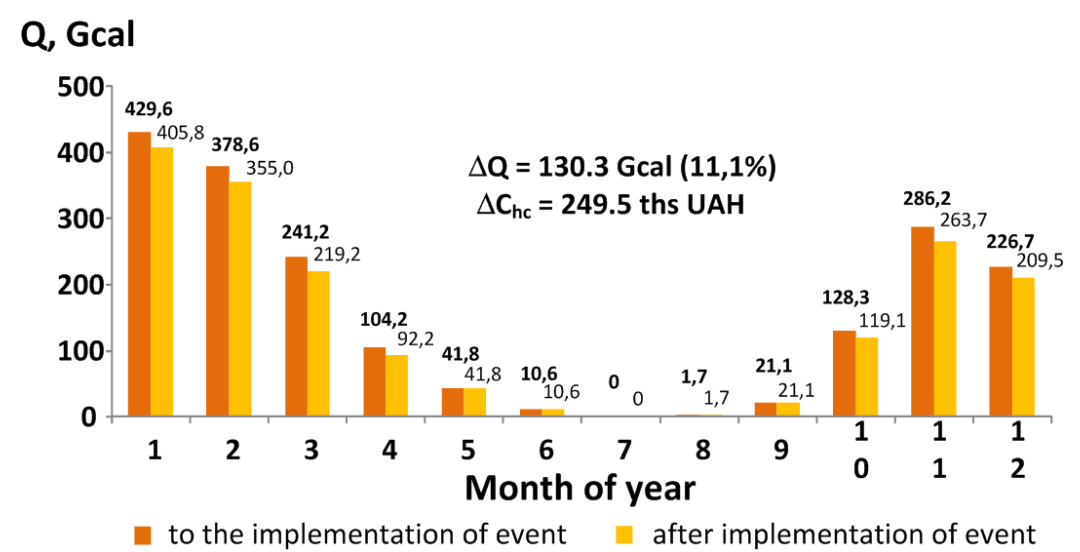

Fig. 13. The results of evaluating the efficiency of use at the full-scale object № 2 of the HERZ Smart Comfort system

Moreover, the relevant indicators of environmental and economic effects are: reduction of natural gas consumption - 16,5 thousand $\mathrm{m}^{3}$, reduction of $\mathrm{CO}_{2}$ and $\mathrm{NO}_{\mathrm{x}}$ emissions into the atmosphere $-32,0$ tons and 0.035 tons, respectively; reduction in heating charges $-249,5$ thousand UAH.

Evaluation of the effectiveness of using an alternative source of heat supply - heliosystems. To determine the main energy characteristic 
of the heliosystem - its average monthly thermal productivity $\mathrm{Q}_{\mathrm{m}}(\mathrm{kW} \cdot \mathrm{h})$, the following formula is used ${ }^{16}$ :

$$
\mathrm{Q}_{\mathrm{m}}=\mathrm{E}_{\mathrm{S}} \cdot \mathrm{s} \cdot \eta \cdot \mathrm{N}
$$

where $E_{S}$ - the specific average monthly thermal output of solar collectors in the Kharkiv climate zone, $\mathrm{kW} \cdot \mathrm{h} /\left(\mathrm{m}^{2} \cdot\right.$ day) (see table 4); $\mathrm{s}-$ the surface area of one solar collector, $\mathrm{m}^{2}$ (for collectors of the recommended type is $\left.2,55 \mathrm{~m}^{2}\right) ; \eta$ - solar collector efficiency $(0,794$ for recommended type collectors $\left.{ }^{17}\right) ; \mathrm{N}$ - the number of solar collectors in the solar system.

Table 5

Calculation results of thermal energy savings in all rooms of the fullscale object № 2 subject to optimization of the temperature regime

\begin{tabular}{|c|c|c|c|c|}
\hline Month & $\begin{array}{c}\text { Need for } \\
\text { thermal } \\
\text { energy before } \\
\text { TC, Gcal }\end{array}$ & $\begin{array}{c}\text { Need for } \\
\text { thermal energy } \\
\text { after TC, Gcal }\end{array}$ & $\begin{array}{c}\text { thermal energy } \\
\text { saving as a } \\
\text { result of TC, } \\
\text { Gcal }\end{array}$ & $\begin{array}{c}\text { Share of } \\
\text { energy } \\
\text { saved, \% }\end{array}$ \\
\hline January & 258 & 234,2 & 23,8 & 9,2 \\
\hline February & 255 & 231,4 & 23,6 & 9,3 \\
\hline March & 185 & 163,0 & 22 & 11,9 \\
\hline $\begin{array}{c}\text { April (for the } \\
\text { period from } \\
\text { 01.04.19 to } \\
14.04 .19)\end{array}$ & 66 & 54,0 & 12 & 18,2 \\
\hline $\begin{array}{c}\text { October (for the } \\
\text { period from } \\
15.10 .19 \text { to } \\
31.10 .19)\end{array}$ & 59 & 49,8 & 9,2 & 15,6 \\
\hline November & 188 & 165,5 & 22,5 & 12,0 \\
\hline December & 160 & 142,8 & 17,2 & 10,7 \\
\hline Heating season & 1171 & 1040,7 & 130,3 & 11,1 \\
\hline
\end{tabular}

${ }^{16}$ Вовчак В., Тесленко О., Самченко О., Сушкова Д. Кращі $з$ доступних технологій для житлово-комунального господарства України. Керівництво 3 відбору технологій. Під ред. С. Єрмілова. «Поліграф плюс», 2016. 134 с.

Характеристики сонячного колектору BUDERUS SKT 1.0s. URL : https://220volt.com.ua/solnechnij-kollektor-buderus-skt-1-0s-8718532821. 
The results of calculations of the average monthly and annual heat capacity of the heliosystemy, which can be located in the recommended area (Fig. 14), indicate that it is capable of producing 376,7 Gcal of thermal energy per year, or 20,2\% of the existing volume of heat of the building of the communal enterprises CI KhPCYC building.

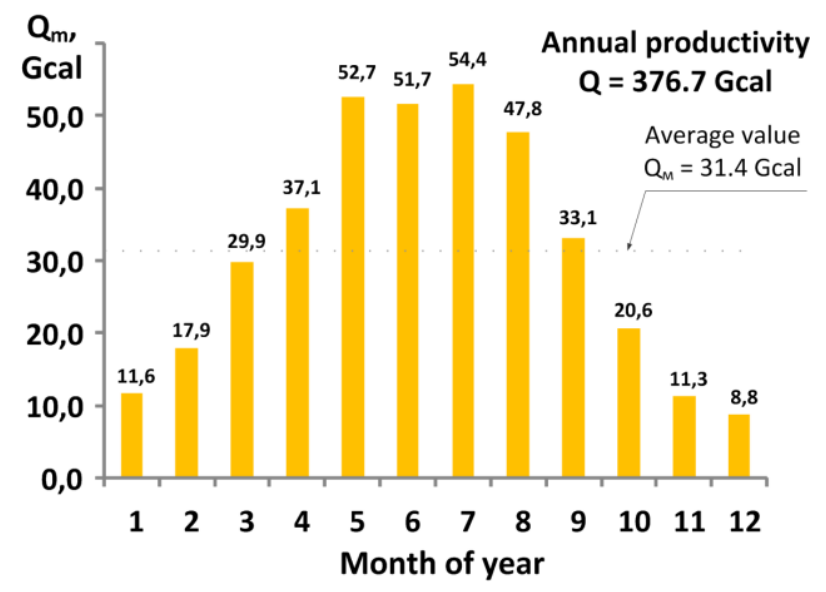

Fig. 14. Diagram of the average monthly thermal output of a heliosystem from 180 SKT 1.0 collectors

If necessary heat output heliosystems can be increased by 2.3 times - up to $880 \mathrm{Gcal} /$ year, if you use the roof of the building to accommodate an additional quantity of 240 solar collectors -4 rows of 60 pieces (Fig. 15).

A multicriteria assessment of the efficiency of use of the heliosystem shows that this measure allows you to additionally obtain such an annual effect: energy - an additional amount of thermal energy - 376,7 Gcal or $20,2 \%$, of which it can be used: the building of the communal enterprises CI KhPCYC - 212,3 Gcal or 11,4\%, in other buildings (from May to September) - 164,4 Gcal or 8.8\%; In this case, the demand of communal enterprises CI KhPCYC in thermal energy is provided: in the period from May to September - by $100 \%$, in the heating period - by $2,8 \ldots$ $35,6 \%$; ecological - reduction of natural gas consumption 47,7 thousand $\mathrm{m}^{3}$, reduction of $\mathrm{CO}_{2}$ and $\mathrm{NO}_{\mathrm{x}}$ emissions $-92,6$ tons and 0,101 tons, respectively; economic: reduction of payment for thermal energy - 721.3 thousand UAH; The payback period of the event is 5 years. 

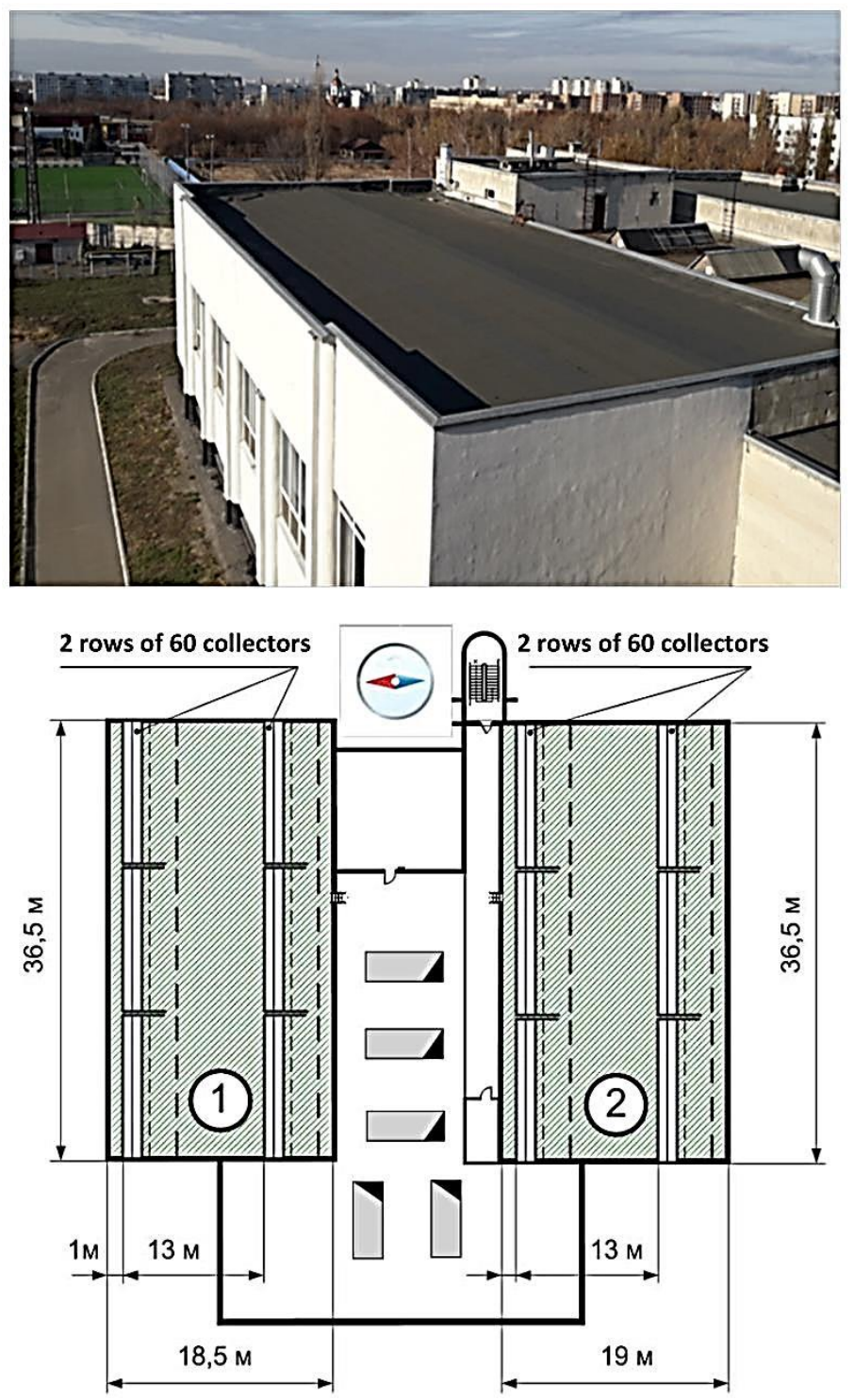

Fig. 15. General view of the additional location of the heliosystem 


\section{CONCLUSIONS}

1. Created a method of multicriteria performance evaluation of the effectiveness of energy-saving measures for the thermal energy of buildings. The following indicators are used as criteria for assessing the effectiveness of the studied measures in this method: 1) energy effect the absolute and relative value of the saved thermal energy; 2) environmental effect - the amount of fuel saved, reducing emissions of greenhouse gases and pollutants into the atmosphere; 3) economic effect - the cost of saved thermal energy and fuel.

2. The practical realization of the created method on the basis of 2 full-scale objects: № 1 - a 3-story fragment of the administrative building of O.M. Beketov National University of Urban Economy in Kharkiv with a total heated area of $225 \mathrm{~m}^{2}$ and № 2 - the building of the communal institution «Kharkov Palace of Children and Youth Creativity» with a total heated area of more than $13700 \mathrm{~m}^{2}$.

3. For full-scale object № 1, the effectiveness of using «smart home» technology to control the thermal conditions of the building's premises using the HERZ Smart Comfort automated system has been evaluated. The following performance indicators for the use of this measure for the heating period are thermal energy savings $-3734 \mathrm{kWh}$ or $17 \%$, reduction of natural gas consumption for heating $-406,4 \mathrm{~m} 3$, reduction of $\mathrm{CO}_{2}$ and $\mathrm{NO}_{\mathrm{x}}$ emissions $-789.1 \mathrm{~kg}$ and $0,86 \mathrm{~kg}$, respectively reduction of payment for consumption of thermal energy - $4041 \mathrm{UAH}$ and fuel $4441 \mathrm{UAH}$.

4. For full-scale object № 2 was evaluated the effectiveness of 2 energy-saving measures: controlling the thermal conditions of the building's premises with the HERZ Smart Comfort system and using an alternative heat source - heliosystem, which consists of 180 solar collectors. It was established that the 1-st event has such an annual effect: energy - 130,3 Gcal or $11.1 \%$; ecological: reduction of natural gas consumption - 16,5 thousand $\mathrm{m}^{3}$, reduction of $\mathrm{CO}_{2}$ and $\mathrm{NO}_{\mathrm{x}}$ emissions into the atmosphere -32.0 tons and 0.035 tons, respectively; economic: reduction of payment for searing - 249,5 thousand UAH; 2-nd event has such an annual effect: energy - an additional amount of thermal energy - $376.7 \mathrm{Gcal}$ or $20,2 \%$; ecological - reduction of natural gas consumption $-47,7$ thousand $\mathrm{m}^{3}$, reduction into the atmosphere of $\mathrm{CO}_{2}$ and $\mathrm{NO}_{\mathrm{x}}$ emissions - 92,6 tons and 0,101 tons, respectively; economic: reduction of payment for thermal energy - 721.3 thousand $\mathrm{UAH}$; the payback period of the event is 5 years. 
5. The research results showed such properties of the proposed method for evaluating the effectiveness of energy-saving measures, such as: high information content of the results, providing the possibility of multicriteria optimization of the parameters of heat supply systems and heat consumption of the research object, ability to improve by increasing the number of studied performance indicators.

\section{SUMMARY}

The work is devoted to solving an urgent scientific problem increasing the informativeness of methods for assessing the effectiveness of energy saving measures in the areas of heat supply and heat consumption. The purpose of the research was to create and implement a method for multicriteria evaluation of the effectiveness of energy-saving measures for the thermal energy of buildings. The following indicators are used as criteria for assessing the effectiveness of the studied measures in this method: 1) energy effect - the absolute and relative value of the saved thermal energy; 2) environmental effect - the amount of fuel saved, reducing emissions of greenhouse gases and pollutants into the atmosphere; 3 ) economic effect - the cost of saved thermal energy and fuel. The practical implementation of the created method was carried out on the basis of 2 full-scale objects: № 1 - a 3-story fragment of the administrative building of Kharkov National University of Municipal Economy them. A.N. Beketova with a total heated area of $225 \mathrm{~m}^{2}$ and № 2 - the building of the communal institution "Kharkov Palace of Children and Youth Creativity" with a total heated area of more than $13700 \mathrm{~m}^{2}$. For full-scale object № 1, the effectiveness of using «smart home» technology to control the thermal conditions of the building's premises using the HERZ Smart Comfort automated system has been evaluated. For full-scale object № 2 was evaluated the effectiveness of 2 energy-saving measures: controlling the thermal conditions of the building's premises with the HERZ Smart Comfort system and using an alternative heat source - heliosystem, which consists of 180 solar collectors. The research results showed such properties of the proposed method for evaluating the effectiveness of energy-saving measures, such as: high information content of the results, providing the possibility of multicriteria optimization of the parameters of heat supply systems and heat consumption of the research object, ability to improve by increasing the number of studied performance indicators. 


\section{REFERENCES}

1. The Covenant of Mayors for Climate and Energy Reporting Guidelines / Covenant of Mayors \& Mayors for climate and energy. Adapt Offices and the Joint Research Centre of the European Commission, $2016.78 \mathrm{p}$.

2. Alibekova A., Shaimerdenova G., Agilbaeva M. Ecolodica problems of thermal power plants. Journal of Industrial Technology and Engineering, 2013. Вип. 4(09). Р. 40-44.

3. Варламов Г.Б., Дідик І.С. Основні особливості реалізації принципу екологічної рівноваги на екологічному об'єкті. Молодий вчений, 2016. Вип. 1/ Ч. 3. С. 104-107.

4. Маляренко В.А., Щербак I.С. Аналіз споживання паливноенергетичних ресурсів України та їх раціонального використання. Вісник НТУ «ХПІ». Серія: Енергетичні та теплотехнічні процеси й устаткування, 2013. Вип. 14(988). С. 118-126.

5. Купалова I. Визначення обсягів викидів стаціонарними джерелами. Вісник. Офімійно про податки, 2016. Вип. 32(889). C. 32-37.

6. Тарифи на теплову енергію для бюджетних установ, інших споживачів (крім населення) i релігійних організацій. КП «Харківські теплові мережі». URL : http://www.hts.kharkov.ua/ KPHTS_v2_public_info_tarify.php.

7. Исаченко В.П., Осипова В.А., Сукомел А.С. Теплопередача : учебник для вузов. Энергия, 1975. 488 с.

8. HERZ Smart Comfort: дистанционное управление комфортом дома. URL : https://voltar.com.ua/news/herz-smart-comfortdistantsionnoe-upravlenie-komfortom-doma.html.

9. Polivyanchuk A., Kovalenko Y. Improving the efficiency of thermal energy use when heating buildings through the introduction of technologies «smart home». Вісник Харківського національного університету ім. В.Н. Каразіна. Серія «Екологія». 2018. Вип. 19. С. 119-126. DOI: 10.26565/1992-4259-2018-19-12.

10. Плоскі сонячні колектори Logasol SKT 1.0. Будерус Україна. URL : https://www.buderus.ua/products/solar/skt10.html.

11. Вовчак В., Тесленко О., Самченко О., Сушкова Д. Кращі з доступних технологій для житлово-комунального господарства України. Керівництво з відбору технологій / Під ред. С. Срмілова. «Поліграф плюс», 2016. 134 с.

12. Дорогунцов С.І., Коценко К.Ф., М.А. Хвесик. Екологія : підручник. КНЕУ, 2005. 104 с. 
13. Прутська О.О., Федик О.Ю. Сучасний стан та проблеми розвитку альтернативної енергетики в Україні. Збірник наукових пращьь ВНАУ, 2012. Вип. 1(56). Т. 2. С. 158-164.

14. Штен I. Аналіз конструкцій геліосистем гарячого водопостачання, які використовуються в Україні. Збірник тез Міжнародної студентської науково-технічної конферениії Природничі та гуманітарні науки. Актуальні питання, 2018. Т. 1. C. $131-132$.

15. Характеристики сонячного колектору BUDERUS SKT 1.0s. URL : https://220volt.com.ua/solnechnij-kollektor-buderus-skt-1-0s8718532821 .

\section{Information about authors:} Polyvianchuk A. P., Doctor of Technical Sciences, Professor, O. M. Beketov National University of Urban Economy in Kharkiv 17, Marshall Bazhanov, str., Kharkiv, 61002, Ukraine

Belousov I. V., Candidate of Technical Sciences, Associate Professor, Kherson State Maritime Academy Ushakova avenue, 20, Kherson, 73000, Ukraine

Semenenko R. A., Postgraduate Student at the Department of Engineering Ecology of Cities O. M. Beketov National University of Urban Economy in Kharkiv 17, Marshall Bazhanov, str., Kharkiv, 61002, Ukraine 